Милан Д. АЛЕКСИЋ

Универзитет у Београду

Филолошки факултет
Оригинални научни рад

Примљен: 24. 12. 2016.

Прихваћен: 10. 02. 2017.

\title{
ОГЛЕДИ ЉУБОМИРА НЕДИЋА **
}

\begin{abstract}
У раду су анализирани критички и теоријски огледи Љубомира Недића, као и други текстови (предавања, чланци) који се могу посматрати као есеји. Недић је одабрао есејистички приступ у писању великог броја својих текстова јер их је на тај начин приближио широј публици. Почевши од јавних предавања држаних крајем девете деценије XIX века, преко огледа објављених у књигама, до чланака из часописа Српски преглед, Недић је користио предности есеја у односу на научну расправу и тиме је књижевну критику, између осталог, приближио читаоцима, али не прелазећи границу која би је одвела у произвољност и потпуну субјективност.

Кључне речи: књижевна критика, оглед, есеј, покушај, теорија књижевности, Љубомир Недић, Српски преглед.
\end{abstract}

У српској књижевности крајем XIX и почетком XX века есеј је највише познат као књижевнокритички текст, те есеји ове врсте бивају блиски научним расправама. Њих су писали Марко Цар, Љубомир Недић, Богдан Поповић, Јован Скерлић, Павле Поповић и други. Књижевнокритички есеј се разликује од књижевног есеја, на првом месту, на стилском плану, али и на плану излагања будући да значајну улогу у критичком есеју имају научне методе чињеничног или логичког доказивања. Отуда и у прецизирању овог жанра као књижевно-научне врсте долази до наглашавања његове хибридности и повезаности, са једне стране, са уметношћу, а са друге стране, са науком. У српској књижевности првим правим књижевним есејистима се обично сматрају Исидора Секулић и Станислав Винавер. ${ }^{1}$ Будући да се есеј у српској књижевности најпре појављује као критички жанр, па тек потом књижевни, често долази до терминолошких недоумица.

${ }^{*}$ milan.aleksic@fil.bg.ac.rs

** Рад је настао у оквиру НП 178026 „Проучаваоци књижевности у српској култури друге половине двадесетог века" на Филолошком факултету Универзитета у Београду, који финансира Министарство просвете, науке и технолошког развоја Републике Србије.

${ }^{1}$ Видети: Речник књижевних термина (РКТ 1992: 202). 
Љубомир Недић је своје књижевнокритичке радове сматрао - критичким студијама будући да је овај термин поставио као поднаслов својим књигама Из новије српске лирике и Новији српски писции. Полазећи за Недићевим одређењем, Павле Поповић је, приређујући радове из Недићеве заоставштине, искористио исти термин за наслов књиге објављене у Колу СКЗ 1910. године. Једини Недићев текст који у наслову има назив књижевно-научне врсте јесте Покушај о литерарном укусу и њиме нам је аутор указао и на сопствено поимање значења самог термина, које је у сагласју са његовим изворним значењем. Нортроп Фрај ће, више од пола века након Недића, пишући о могућностима књижевне критике у књизи Анатомија критике, на исти начин поимати есеј у његовом „изворном значењу појма као огледа или недовршеног покушаја" (Фрај 2007: 9). Полазећи од наведених ставова, а имајући у виду целину Недићевог опуса, намеравамо да утврдимо да ли се различити типови његових текстова (неки од њих су настали као текстови предавања на популарне теме оног времена, неки су настајали као прилози за часописе, а знатан број је објављен као део књиге), могу посматрати као есеји или у случајевима критичких студија, са значајним уделом есеја.

Љубомир Недић има посебно значајно место у оквирима српске науке о књижевности и његова појава „у српској књижевној критици обележава прекретницу” (Тартаља 1977: 7). Недић је, одбацивши спољашњи приступ проучавању књижевног дела и окренувши се унутрашњем или иманентном приступу, својим књижевнокритичким радом засновао модерну српску књижевну критику. Објављивање збирке критичких студија под насловом Из новије српске лирике 1893. године означило је тренутак у коме је извршен прелаз са спољашњег на унутрашњи приступ у српској науци о књижевности. Преокрет је обухватио не само измену приступа већ и методологију проучавања праћену и употребом новог вредносног мерила. Недић, дакле, одбацује импресионистичко-биографску методу свог непосредног претходника у књижевној критици, Светислава Вуловића, и уводи естетичко мерило у књижевну критику. Увођење новог мерила у књижевну критику повезано је било и са одбацивањем утилитарног схватања функције књижевности Светозара Марковића. Сви наведени Недићеви ставови имали су далекосежне последице.

Прву групу Недићевих радова чине објављени текстови јавних предавања о популарним темама онога времена: „О хипнотизму” (1888), „О сну и сновима” (1888), „О софизмима” (1889), „О Хамлету” (1892), и „О песимизму” (1894). Зоран Гавриловић је за њих написао да су „били неоригинални, суви и незанимљиви” (Гавриловић 1960: 9), али они често укључују директно лично искуство самог аутора, те се не можемо сложити да су у потпуности неоригинални. Ови Недићеви текстови су есеји у изворном значењу јер су писани на основу личног искуства, а не ослањањем на научне методе, доказивање и логично закључивање, што нам доказују делови текстова у којима се Недић појављује и као учесник догађаја о којима пише. У овим есејима Недић се трудио да најпре пружи информативну основу својим читаоцима, те да прецизно дефинише проблем којим хоће да се бави и да уклони све по- 
пуларне заблуде које се о њему појављују. У есеју „О хипнотизму” он укратко представља развитак технике хипнотисања, а онда укључује сопствено искуство препричавајући сеансу хипнотисања којој је присуствовао у Лондону, да би на крају текста посветио пажњу могућем научном објашњењу технике хипнотисања, односно његовог дејства на људе. И у есеју „О сну и сновима” Недић, иако укратко заиста представља резултате до којих је наука дошла у објашњавању људске потребе за сном, он убрзо посеже са примерима из свог искуства. У есеју под насловом „О песимизму” након уводних информација о самом термину и његовом етимолошком пореклу Недић инсистира на објашњењу древности ових погледа на свет и њиховом постојању и пре него што су термини оптимизам и песимизам уопште сковани, те указује на честу грешку у веровању да су песимизам измислили Бајрон и Шопенхауер. Недићев основни циљ је да укаже на главне облике у којима се песимизам јавља, полазећи од показивања да су религије попут будизма или хришћанства у основи песимистичке, па све до развоја песимизма у XIX веку.

Есеј „О софизмима” истоветно је написан, те Недић и у њему полази од етимологије термина, па указује да на основу значења софизма, као привидног доказа коришћеног у сврху обмане, можемо разликовати два типа софизама, софизме срца и софизме разума (од којих су само ови други прави софизми по логици). Софизми срца заправо су одговорни и за постојање тврдокорних предрасуда које се тешко повлаче, те Недић као аргумент наводи примере друштвених реакција на напретке науке, узимајући два речита примера; одбијање могућности за обарање геоцентричног модела света или друштвену реакцију изазвану појавом Дарвинове теорије еволуције. На самом крају овог есеја Недић је, врло интересантно, закључио да, уколико нам је немогуће да избегнемо коришћење софизама, ипак даје предност софизмима срца сматрајући их мање погрешним.

У есеју „О Хамлету” (1892) Недић је изнео сопствени поглед на карактер Шекспировог јунака на основу свог предавања одржаног три године пре објављивања рада. У есеју нема осврта на традицију тумачења Хамлетовог карактера нити се уопште помињу други аутори, те је јасно да смо поново на пољу есеја, а не научне расправе. Но, ипак у свим до сада наведеним радовима Недић се труди да укаже на достигнућа савремене науке, те се чини да он настоји да оствари спој академске расправе и занимљиве козерије, а управо је указивањем на такав спој Марко Цар дефинисао есеј у раду под насловом „Есеј о есеју” (в. Цар 1931: 63). Иако се при избору тема и начину организације текста Недић руководио и одабиром тема које ће бити занимљиве за ширу публику којој су есеји намењени, њега није ниједног тренутка напуштала посвећеност критичкој провери и испитивању предмета пре коначног закључивања. Наравно, у овим есејима посвећеним популарним темама, тек се у назнакама препознају намере ${ }^{2}$ проучаваоца, али будући да хронолошки

${ }^{2}$ Тако се први обриси теоријског става о потреби усмеравања критичке анализе налазе у есеју „О сну и сновима”: „Гледајући какав сложен предмет, ми се питамо, из чега је он састављен, као што, обрнуто, када видимо какав саставак, или део какве сложене ствари, помишљамо на целину. У овим асоцијацијама су, опет, основе две важне радње нашег духа: Анализе, која разлаже и 
претходе Недићевим књижевнокритичким радовима, они сведоче о начелној усмерености писца, без обзира на различитост предмета који су разматрани.

Другу групу Недићевих радова чине књижевнокритички огледи. Недић их је називао критичким студијама, а касније се као синоним појављивао и термин расправа. Иво Тартаља је, пишући о Недићевим расправама, приметио да се на њиховом крају, по правилу, обликује уопштена карактеристика „и у једном лежерно-пророчком тону слове о судбини која песника очекује” (Тартаља 1977: 27). Полазећи од овог одступања од строгости форме студије, односно расправе, чини се да је ове радове могуће видети као критичке есеје, односно критичке огледе, јер они, и поред начелног усмерења ка научном расправљању и изношењу аргумената на основу којих се логично закључује и доноси суд, ипак нису у потпуности прецизна, научна дела која би се могла без остатка назвати студијама. Недићеви радови заправо представљају расправе есејистичког типа које су постављене на прецизне књижевнотеоријске темеље, али нису изведене прецизном аналитичком методом, већ су прилично једностране, па самим тим и непрецизне. Због таквог методолошког приступа, Недићеве критичке студије или расправе заправо се у нашој визури приближавају есеју. Због тога их можемо називати и критичким огледима, а управо такво одређење даје и Речник књижевних термина, у коме је наглашена посебна природа критичког есеја који бива близак расправи. Оваквом одређењу иде у прилог и чињеница да су српски критичари почетком XX века често своје радове именовали као огледе. Богдан Поповић је своје критичке радове назвао огледима како би их одвојио од уобичајеног схватања књижевне критике, као „критике импресионистичке” (Поповић 2001: 1). Недићеви критички огледи имају истоветну структуру. У њиховој основи налази се књижевнотеоријски став који се примењује на појединачне случајеве, чиме се потврђује почетна претпоставка. Специфичност Недићеве методе била је управо у везивању за извесне опште судове теорије књижевности који су били проверавани анализом, но та анализа није била потпуна, већ је била једнострана и пристрасна, чиме је и њен резултат био некомплетан.

Пишући о Ђури Јакшићу и Јовану Јовановићу Змају, на пример, Недић је пошао од природе стваралачког чина, наглашавајући да је за песника од прворазредне важности надахнуће, док је песничку вештину сматрао мање важном, никако неважном, али ипак другоразредног значаја. Наиме, Недић је сматрао да надахнуће може да искупи недостатак песничке технике, али није прихватао могућност искупљења недостатка надахнућа врхунском уметничком техником. И у огледу о Јакшићевом песништву и у огледу о Змајевом песништву, Недић је полазио од истоветног књижевнотеоријског става, заступајући становиште ентузијастичке поетике, и то не изворно античко схватање какво дефинише Платон у дијалогу Ијон, већ њене варијанте створене у време романтизма по којој извор стваралачке енергије више није божански већ се налази у бићу песника. Полазећи од става да је за песничко стварање

Синтезе, која слаже и саставља. То су, углавноме и сасвим уопште закони, по којима се удружују наше представе" (Недић 1888: 8). 
кључно надахнуће, Недић је у поменута два рада представио структуру свог критичког огледа, али је у њима изнео два различита суда. Јакшића је изузетно хвалио као песника у чијем стварању надахнуће има важно место, док је Змаја сматрао више стихотворцем него песником јер му је, по Недићевом суду, најчешће недостајало надахнуће, те је стварао само на основу песничке вештине. Недићев напад на Змаја, као и на Лазу Костића, дуго ће бити помињани у српској науци о књижевности као примери негаторске критике и пажња ће више бити усмеравана на ванкњижевне разлоге за Недићево обрушавање на признате величине српске књижевности него на разумевање његовог метода и резултата спроведене анализе.

Поглед на структуру ових критичких огледа показује да Недићева анализа није била подробна и свеобухватна, већ једнострана, подређена доказивању почетне претпоставке, одређене на основу општег суда, а не аналитичког испитивања, те је због своје искључивости сувише непрецизна. Змајевом и Костићевом песништву Недић је тако само тражио и налазио мане, свесно заобилазећи добре особине њихових песничких дела. Недић је на овај начин демонстрирао моћ логичке методе, али није успео да оствари критичку методу која би била прецизна и довољно исцрпна да би давала поуздане закључке. Такву аналитичку методу у српској књижевној критици формулисаће Недићев ученик, Богдан Поповић.

Трећу групу Недићевих радова чине књижевнотеоријски огледи, чији број није велики у Недићевом опусу, а свакако је међу њима најзначајнији „Покушај о литерарном укусу” у чијем наслову се види аргумент за овакво одређење жанра. Овај оглед Недић је започео да пише у септембру 1892. године, о чему је сведочио Павле Поповић, приређујући рукописе из Недићеве заоставштине 1910. године. „Покушај” је објављен постхумно у Српском къижевном гласнику 1906. године, а Недић га вероватно није завршио зато што је као уредник у прва три броја часописа Српски преглед објавио оглед Богдана Поповића под насловом „О васпитању укуса” 1895. године. Необично подударање тема одсликава стање духа времена и показује сличност у тежњама различитих проучавалаца.

Недић је на самом почетку „Покушаја о литерарном укусу”, доводећи у питање тачност латинске изреке по којој о укусима не вреди расправљати, желео да нагласи предмет свог истраживања - трагање за константним елементима који сачињавају књижевни укус. Он је желео да укаже на непотребно преувеличавање субјективног карактера укуса и почетни аргумент којим се користио био је везан за могућност постојања естетике као дисциплине која би била немогућа у случају апсолутне супремације субјективности у области лепог. Недић заправо бира општу аргументацију, избегавајући специјалистичко расправљање, чиме нам показује начелну опредељеност за есеј или оглед као жанр. Покушај о литерарном укусу Недић је наменио широј публици и због тога му је прелазна форма есеја највише погодовала. Он је имао на уму практично деловање и утицај на ширу публику којој се обраћа, па су томе прилагођени и стил писања и аргументација. 
У „Покушају о литерарном укусу” Недић је пажњу усмерио на одређивање литерарне вредности дела, при којој се разликују променљиви фактори, утицаји који вредност неког књижевног дела опредељују у различита времена, сасвим независно од његове праве вредности, а са друге стране, непроменљиви, стални фактори који чине ту праву, унутрашњу вредност. Он је сматрао да ће одређењем ових константних фактора укуса имати и поуздано мерило за процењивање не само литерарног укуса већ и књижевних дела, а двострукост у вредности дела послужила му је да објасни променљивост судова о књижевним делима у току времена. Блискост књижевних дела са духом времена Недић је препознао као кључан разлог за већу прихваћеност појединих дела у одређеном времену: „Отуда је и дошло да су дела што су давала израза ономе што је покретало духове, њиховим осећајима и тежњама, налазила свуда одзива" (Недић 1906: 289). Што је дело више давало израза расположењу духова, то је било више цењено, а при промени духа времена, некада високо вреднована дела падала су у заборав. Други фактор који је Недић посебно издвојио био је везан за менталитет, односно народни карактер, у духу деветнаестовековних друштвених теорија, назван раса, под чиме се заправо мислило на особине народне. Истина, Недић наглашава неадекватност апсолутног истицања народних особина будући да је антрополошки гледано, човеково порекло јединствено питање.

Не треба сметати с ума да расе, поред све различности њихове, имају вазда и нечега заједничког, нечега што је људима свију раса својствено, и да се отуда, у животу и најразличитијих раса, јављају углавном исти појави, само локално, према раси, у нечему измењени” (Недић 1906: 291).

У променљиве факторе који утичу на промену књижевног укуса Недић је убројао и човекову сталну потребу за новином која произвољно мења укус, а неједнакост укуса која се појављује у различитим добима човековог живота том мењању даје сталан правац. Насупрот наведеним променљивим факторима, као константни елемент који, поред свих колебања и мењања литерарног укуса кроз време, показује сталност и утврђеност, Недић наводи форму, облик књижевног дела. Он улаже знатан напор у прецизно дефинисање појма форме наглашавајући његову већу сложеност у односу на одабир сталних облика стиха или строфе. За њега појам форма означава песничку обраду: „Када о каквој песми кажемо да је лепа [...] онда то, [...] значи поглавито да је она лепо у речи сложена. И овај сложај речи, то је оно што је чини лепом" (Недић 1906: 358). Недићева синтагма СЛОЖАЈ РЕЧИ означавала је заправо стваралачки избор лексике, али и њен распоред унутар целине дела који бива извор естетског и који се не може нарушити без губитка уметничке вредности. Недић наводи тешкоће везене за превођење књижевних дела као аргумент за своју тврдњу да је структура књижевног дела важна, као и одабир елемената који је чине, односно, одабир речи ${ }^{3}$ и њихов распоред. Недић је,

\footnotetext{
3 „Речи са својим секундарним значењем и безбројним асоцијацијама што су за њих везане - елементи система конотације, [...] граде спојеве који се ни на који начин не могу остварити” (Тартаља 1977: 11).
} 
указујући на важност распореда речи, довео у везу одабир речи који стваралац књижевног дела чини са ефектима које жели да произведе код примаоца, тиме заправо започињући теоријско разматрање које би водило ка стилистичкој критици и на тај начин је означио пут којим би његова теоријска мисао ишла да је овај оглед био завршен и објављен крајем XIX века.

Недић је на почетке својих књига критичких огледа поставио радове који су за предмет имали књижевну критику. Књигу Из новије српске лирике 1893. године започео је огледом „Новија српска лирика и њени критичари” у ком је истакао неколико основних типова приступа књижевној критици. Разматрајући методе својих претходника, Недић разликује три типа критике. Први тип шаљиво је називао „методом коњичких скокова” јер је, при његовом коришћењу, сва критичарева пажња усмерена на састављање слике или историје песника на основу елемената узетих из његових песама. Недић у потпуности дискредитује наведену методу одузимајући јој било какву научну основу и сводећи је на њој примерени ниво стилистичког вежбања. Други тип критичке методе коју Недић идентификује заправо је импресионистичко-биографска метода Светислава Вуловића коју Недић назива „природном критиком” и којој замера превелико ослањање на субјективност и „ситно и тесногрудо цењење писаца по њиховој приватној личности” (Недић 1893: 11). Трећи тип критичке методе Недић је препознао код Светозара Марковића и назвао га „реалном критиком”. Он је Марковићевој методи замерао једностраност, свођење критичког мерила на оцену садржаја књижевног дела чиме се заправо питање функције књижевности поставља у први план јер се дело вреднује са гледишта корисности. Поред указивања на типологију књижевне критике његовог времена, Недић је у овом огледу назначио неке од својих веома важних књижевнотеоријских ставова које препознајемо много касније објављене у „Покушају о литерарном укусу”, па је тиме својства свог огледа одредио негде на граници између критичке анализе и теоријског огледа.

Своју другу књигу Новији српски писции из 1901. године Недић је започео књижевнотеоријским огледом „О књижевној критици” наглашавајући да његова природа, иако рад назива студијом, није у потпуности научна, већ да се текст заиста може сматрати текстом есејистичке природе. „Што мислим овде изнети, то није систематска расправа, него само неке мисли о њој, субјективна мњења, ништа више - исповест моја као критичара, ако се хоће" (Недић 1901: 8). Недић, одређујући основне типове књижевне критике, прецизира и њихове функције, као и важност за саму књижевност.

Критике, у опште узев, има од три врсте: једна, која редовно прати појаве на пољу књижевности, доноси дневне новости и догађаје књижевности, бележи их и процењује; друга, која расправља општа питања књижевности, питања укуса, праваца у њој, и потреба њених, која треба да упућује, донекле даје и правац књижевности; и напослетку, трећа, која се бави проучавањем књижевних дела (Недић 1901: 8).

Првом типу, тако, не придаје велику важност јер је вредност дневне критике пролазна. Иако већу важност види у другом типу критике који треба да се бави великим, општим питањима књижевности, заправо ономе што савремена наука о књижевности види као задатак теорије књижевности, Недић 
ипак наглашава секундарност проучавања у односу на књижевно стварање. Критика увек иде за књижевношћу, и, премда она може да утиче на књижевност, она се ипак поима као пратилац књижевности. Трећи тип критике Недић препознаје у анализама самих књижевних дела. Он, наглашавајући потребу да се књижевно дело проучава независно од било чега другог, понавља осам година раније изречен став о потреби иманентног приступа проучавању књижевности. Међутим, и поред велике важности коју за читаву српску науку о књижевности има Недићево залагање за увођење унутрашњег приступа проучавању књижевности, у оно време апсолутно иновативног погледа, он има и схватања која нису била толико модерна. Тако, на пример, он сматра критику делом уметности, те и критичара види као уметника, а не као научника. Удео субјективности који оставља у погледу на критичара везан је за осећање и проживљавање књижевног дела. Недић је заправо сматрао да у критичком послу увек остаје један део субјективног и у томе није грешио јер се никада не може до краја остварити објективност у критичкој анализи, али несклад његове теоријске поставке која подразумева рационално тумачење естетског квалитета уметничког дела, анализу његове структуре и објашњења склада његових делова, почива у превеликом инсистирању на потреби осећања и проживљавања тог истог дела. Емоционална компонента критичког погледа за Недића је била довољна да критику прогласи уметношћу, а критичара уметником јер је његов циљ видео у представљању лика ствараоца који се налази у делу. Недићева мисао на овом месту је склизнула на странпутицу jep је поставка паралелизма између књижевног критичара и сликара, који обојица имају задатак да прикажу човека, погрешна. Недићева теоријска мисао овде је неусаглашена јер он не увиђа да критика, коју је већ именовао као секундарну у односу на уметност, не може бити истоветна са стварањем зато што не ствара ништа квалитативно ново, већ анализом указује на оно што већ постоји створено у књижевном делу. Недића је завела синтагма „човек у књизи", коју је сковао како би означио разлику у погледу на стваралачку личност писца која се у књизи огледа од његове биографске личности, коју је назвао „човеком иза књиге”. Иако нам је јасно да је Недић био на прагу одређења оних особености стваралаштва које јесу видљиве у самим књижевним делима, оног што се једноставно дефинише као „унутрашња теорија књижевности" коју проучаваоци данас називају поетиком писца, он је није на тај начин дефинисао. Његова синтагма „човек у књизи”, није била довољно диференцирана у односу на представу слике човека, те је отуда било могуће ступити у повлачење сличности између сликара и критичара. ${ }^{4}$ У наставку Недићевог огледа овакво становиште је ублажено истицањем постојања критичара који се са ставом да је критика уметност не слажу, прихватајући да је додирна тачка могућа само „у лепом писању о књижевним делима” (Недић 1901: 15), заправо у потреби и критичара да се користе лепим стилом.

\footnotetext{
${ }^{4}$ „Такав је предмет Критике, и то, уједно, и метода њена. Она је у анализи књиге и синтези човека који је у књизи” (Недић 1901: 23).
} 
Посебан тип Недићевих текстова настао је из практичне потребе током уређивачког рада у часопису Српски преглед јер је уводни чланак у шест од укупно десет ${ }^{5}$ објављених бројева часописа био посвећен неком општем питању од значаја за српску књижевност. Тако су настали чланци: „Српски књижевни језик”, „Српски стил”, „Правопис и интерпункција”, „Српске књиге”, „Српски писци”, „Српска књижевна публика”, а њихов облик је најближи оном што би се данас звало новинарски есеј. Ови есеји су малог обима и заправо су чланци који се користе есејистичким приступом у обради теме. Блискост са есејом потиче из Недићеве намере да не пише расправе већ да, попут аутора изворних есеја, изнесе сопствено мишљење о проблемима српске књижевности без чињеничног и логичког апарата доказивања. Ови Недићеви чланци имају за циљ покретање питања којима су посвећени, они започињу тему и нуде ауторов поглед и став, али представљају само први корак. Њихова заједничка основа је Недићева брига за бољитак српске књижевности јер у свим овим чланцима се од ње и полази указујући на конкретне кораке којима се стање може поправити, било да је у питању нешто што се релативно лако може остварити, као у случају његовог предлога за правопис, било да је у питању проблем који се не може тако лако поправити, као у случају када куди српске писце због недовољне књижевне културе. У Недићевом опусу постоји и један број чланака посвећених питањима српске просвете који су на исти начин саздани као и чланци посвећени књижевним питањима, а и они показују тежњу нашег критичара за увођењем реда и установљавањем јасног поретка у све сфере културног и јавног живота које је сматрао пресудним за културу српског народа.

Делујући као књижевни критичар на првом месту, Недић је увек настојао да своје огледе пише тако да могу да буду намењени врло широкој публици. Због тога су његови радови више огледи него што су расправе у пуном смислу, а нарочито они настали као текстови јавних предавања или као чланци за часописе. Његови критички и теоријски огледи, иако су заиста по својој природи на граници између студије и есеја, заправо су расправе есејистичког типа. Овакво померање унутар природе самих књижевних, односно научних врста одговарало је најпре Недићевом теоријском ставу да је и критика део уметности, а такође је омогућавало већем броју читалаца да прати критичку мисао. Последица прилагођавања расправе есеју и ширење круга читалаца критичких текстова је и узлет српске књижевне критике на самом крају XIX и почетку XX века. Својим критичким огледима Недић је покренуо развој критике у српској књижевности коме су критички огледи потоњих критичара, поменимо само Богдана Поповића и Јована Скерлића, означили потпуну превласт у читавом добу, које је неретко означено управо као доба критике.

\footnotetext{
${ }^{5}$ Уводног чланка нема у бројевима 2 и 8-10 Српског прегледа.
} 


\section{ЛИТЕРАТУРА}

Гавриловић 1960: З. Гавриловић, Љубомир Недић, у: Љ. Недић: Студије из српске књижевности, Нови Сад, Београд: Матица српска, Српска књижевна задруга.

Недић 1888: Љ. Недић, О сну и о сновима, Београд: Краљевско-српска државна штампарија.

Недић 1893: Љ. Недић, Из новије српске лирике, Београд: Штампарија Краљевине Србије.

Недић 1901: Љ. Недић, Новији српски писии, Београд: Штампарија Краљевине Србије.

Недић 1906: Љ. Недић, Покушај о литерарном укусу, Српски књижевни гласник, књ. XVII, св. 2, 123-127, св. 4, 288-295, св. 5, 352-359, св. 6, $438-443$.

Поповић 2001: Б. Поповић, Огледи о српској књижевности, пр. П. Палавестра, Београд: Завод за уџбенике и наставна средства.

PKT 1992: Rečnik književnih termina, D. Živković (ur.), Beograd: Nolit.

Тартаља 1977: И. Тартаља, Човек у књизи Љубомира Недића, у: Студије и критике Љубомира Недића, пр. И. Тартаља, Нови Сад, Београд: Матица српска, Институт за књижевност и уметност.

Фрај 2007: Н. Фрај, Анатомија критике, Београд, Нови Сад: Нолит, Orpheus.

Цар 1931: М. Цар, Олледи и предавања, Београд: Издавачка књижарница Геце Кона.

Milan D. Aleksić

\section{LJUBOMIR NEDIĆ'S ESSAYS}

(Summary)

The paper analyzes both critical and theoretical essays of Ljubomir Nedić, as well as his other texts (lectures, articles) that can be seen as essays. Nedić chose essayistic approach in writing many of his texts because, in that way, they would be more receptive to a broader audience. Beginning with his public lectures from the end of the ninth decade of the nineteenth century, through the critical studies that had major influence of essayistic approach, to articles published in literary magazine entitled Srpski pregled, Nedić has been using the advantages of essays over critical study in order to enhance primarily public interest for literary criticism, and secondly its general influence and position, but without exceeding the limit which would have led literary criticism to the complete arbitrariness and subjectivity. 